\title{
Macroeconomic Effects of Oil on Poverty in Nigeria
}

\section{Paul Collier}

In retrospect, Nigeria can be seen to have experienced a large, temporary trade windfall which was unanticipated and then regarded as permanent. This gave rise to powerful macroeconomic (or general equilibrium) effects which in turn had consequences for the incidence of poverty.

During the period 1973-81, oil augmented GDP by around 22 per cent [Gelb 1985:Tables 4 and 5]. From mid-1981 oil exports were sharply reduced in quantity: between 1981 and 1985 the volume of oil production was only 60 per cent of its level during the preceding five years. At the time this was seen as the post oilboom slump. However, with the collapse in the price structure of the oil cartel in January 1986, which at the time of writing appears to be a long term feature, that period must now be reinterpreted as itself one of abnormally high export revenue. Hence, macroeconomic analysis can conveniently be divided into pre-boom, boom, semi-boom, and post-boom. None of the three changes implied by this division could reasonably have been anticipated.

This temporal sequence constitutes a temporary shock. The macroeconomics of temporary income shocks is still being developed, ${ }^{1}$ but its components are the theory of a temporary (but anticipated) change in income, and that of an unanticipated change in demand. The former is concerned with the asset behaviour required in order to convert a temporary change in income into a permament change in consumption. The latter is concerned with the adjustment process which must occur in factor and commodity markets. Most emphasis is usually placed upon the consequences of errors in expectations in the labour market.

Oil earnings are distinctive in two respects additional to this temporal trajectory: they accrue as foreign exchange and they accrue to the government. The former characteristic entailed that the extra income could only be spent upon tradable goods unless domestic resources were reallocated towards the nontradable sector, this being the standard phenomenon of Dutch disease [see Corden (1984) for a survey]. The latter characteristic massively disturbed the status quo of the public sector budgetary decision process: it was suddenly possible to increase public command over resources and public transfers to favoured private

\footnotetext{
1 For a recent analysis applied to Africa see Bevan et al. (1986a).
}

agents, and to reduce taxation.

The nature of the macroeconomic event dictates the data appropriate for its analysis. The study of the short term adjustment to a demand shock primarily requires indicators of change in the labour market. The temporary windfall aspect suggests that a distinction between consumption and capital formation is desirable. Dutch disease effects require a tradable/ non-tradable distinction, and the government budget a public/private distinction. If there were frequent labour force surveys and if the National Income Accounts and other major data sources came disaggregated into the eight commodity categories implied by the above, instead of the economically almost meaningless industrial classification, it would be possible to get a reasonably clear picture of the macroeconomic effects of the oil windfall. As it is, the reconstruction of the Accounts into appropriate categories is a large research task yet to be undertaken, the present analysis reflecting some tentative steps in that direction. The scanty labour market information provided by national surveys is supplemented by some small-sample surveys conducted in late 1985 and analysed by the author. ${ }^{2}$ There are no national data on the distribution of income, and so quantitative measures of changes in the incidence of poverty are inappropriate. It is only possible to suggest directions of change for particular social groups.

In total we have a data base quite inadequate for the task of piecing together what has happened, and the justification for the ensuing speculation can only be in terms of the dramatic magnitude of the events we analyse.

\section{The Oil Boom, Dutch Disease and 'Boom Famine'}

Dutch disease is a story of resource reallocation between sectors. Although it is referred to as a disease this can be rather misleading, for the reallocation may be entirely desirable. The oil windfall raises expenditure on both internationally tradable and nontradable goods but only enhances the supply of tradables (through imports). This imbalance is equilibrated by an increase in the relative price of

\footnotetext{
2 The surveys were initiated by the West Africa Projects Department of the World Bank and implemented by staff and students of the Department of Agricultural Economics, University of Nigeria, Nsukka.
}

IDS Bullerin, 1987, vol 18 no I. Institute of Development Studies, Sussex 
non-tradables, thereby attracting resources out of the non-oil tradable sector. In developed oil economies (such as the UK) this declining sector is manufacturing. In Nigeria the non-oil tradable sector is primarily export-crop agriculture. In the 1960s crops such as cocoa, oil palm and rubber were the principal source of export revenue. In addition to the export activities, import substitutes are also part of the sector. Potentially this includes both food-producing agriculture and manufacturing; however, food imports were so restricted by import quotas that they are best regarded as quasi-non-tradable. (Although at their peak, food imports met around eight per cent of calorie requirements, the domestic price of rice and maize, the principal imported crops, was generally around three times the world price.)

In Table 1 the National Accounts data are reaggregated into various tradable and non-tradable categories. The relative prices shown in l(a) are sectorspecific GDP deflators and thus denote the price received by producers for value-added rather than the price paid by consumers for commodities. Taking the period $1970-81$ as that during which Dutch disease effects were potentially most pronounced, relative to the pure non-tradable services such as construction the price of the tradable goods, export crops and manufactures indeed fell very substantially, as predicted by the theory. Turning to l(b) we look for signs of the resource shifts which we might expect to be induced by this change in prices. The production of export crops indeed collapses in the most spectacular fashion. The shift of resources out of cocoa and allied activities is Nigeria's analogue of de-industrialisation, though it is far more pronounced. The factor mobility implied by the relative (and absolute) decline in production is evidently considerable. However, manufacturing production increased relative to all other sectors. This appears to be explained not by rising protection but by the non-market allocation of resources, a theme which will be taken up below.

If the behaviour of manufacturing production does not accord with Dutch disease, food production is even more bizarre. The price of food appears to have risen even relative to pure non-traded services and yet its production declined relative to all other sectors except export crops. Clearly, the resource shift out of food production was not induced by this relative price change: rather, the price change was presumably induced by the production shift. But this raises the question as to what caused the production shift.

The price changes derived from the sector-specific GDP deflators are corroborated by reference to the consumer price index (CPI). Between 1970 and 1981 the price of food doubled relative to other goods. ${ }^{3}$ This shows the prices urban consumers faced rather than

\footnotetext{
${ }^{3}$ This estimate rests upon comparing the food price index with the CPl and applying a weight of 0.5 to food in the CPI.
}

those which producers received, but it is likely that with such a large price change food producers enjoyed higher relative prices.

A common proxy for changes in the relative price of tradable and non-tradable goods is the real exchange rate as measured by the comparison of the domestic CPI with the world price of tradable goods expressed in domestic currency. There are many variants of the latter concept. Here we use the US Wholesale Price Index and the dollar-Naira exchange rate. Over the same period the real exchange rate thus measured appreciated by nearly 120 per cent. Although other measures would yield somewhat different numbers they would all show a very large appreciation, indicating a rise in the price of non-tradable goods relative to tradables as implied by the GDP deflators.

Now consider the consequences of Dutch disease for poverty. Potentially there could have been a 'boom famine' [Sen 1981] among export crop producers as a result of the massive deterioration in the relative price of their product. This did not happen. Instead there was a mass exodus of labour from the sector reflected in the collapse in production shown in Tables l(b) and 1(c). The cultivation of low productivity land was abandoned, an example being the vast tracts of untapped rubber trees. Real wages in the sector actually rose between 1973 and 1981 [Collier 1986:Table 3], suggesting that the marginal physical product of labour rose by so much as a result of labour shedding that it more than offset the price change.

Boom famine was avoided because of a very high degree of inter-sectoral labour mobility, and this was probably made possible by two factors. First, it was possible for farmers to switch their labour into food production. As we have seen, the relative price of food was rising and so food sellers were enjoying rising real incomes. However, we have also seen that resources were diverted out of food production, so that it is unlikely that this was the dominant escape route followed by the export crop labour force. Partly, this was because prior to the boom, export crop production was considerably more rewarding than food production, [Collier 1983], so that such a switch might not maintain income at its pre-boom level. The second, probably dominant factor was that urban employment was expanding rapidly during the boom in cities proximate to the export crop sector (notably Lagos and Ibadan). The reason for this expansion reflects not so much Dutch disease as the behaviour of the government.

\section{The Oil Boom, 'Nigeria Disease' and Living Standards}

Oil revenue accrued to the government. By the mid1970 s oil accounted for over three quarters of federal revenue and this triggered a public expenditure 


\section{(a) Relative Prices ${ }^{1}$}

\begin{tabular}{|c|c|c|c|c|c|c|}
\hline \multirow[t]{2}{*}{$Y E A R$} & \multicolumn{5}{|c|}{ MARKET } & \multirow{2}{*}{$\begin{array}{c}\text { NON-MARKET } \\
\begin{array}{c}\text { Government } \\
\text { Services }\end{array}\end{array}$} \\
\hline & $\begin{array}{l}\text { Services, }{ }^{2} \\
\text { etc. }\end{array}$ & Food & $\begin{array}{l}\text { Export } \\
\text { Crops }\end{array}$ & Manufactures & $\begin{array}{l}\text { Consumption } \\
\text { Imports }\end{array}$ & \\
\hline 1970 & 1.00 & 0.86 & 1.19 & - & 0.95 & - \\
\hline 1973 & 1.00 & 1.00 & 1.00 & 1.00 & 1.00 & 1.00 \\
\hline 1981 & 1.00 & 1.21 & 0.71 & 0.76 & 0.77 & 0.63 \\
\hline 1983 & 1.00 & 1.22 & - & 0.66 & 0.76 & - \\
\hline
\end{tabular}

(b) Relative Quantities ${ }^{2}$

\begin{tabular}{|c|c|c|c|c|c|c|c|}
\hline \multirow[t]{2}{*}{$Y E A R$} & \multicolumn{6}{|c|}{ MARKET } & \multirow{2}{*}{$\begin{array}{c}\text { NON-MARKET } \\
\begin{array}{c}\text { Governmen } \\
\text { Services }\end{array}\end{array}$} \\
\hline & $\begin{array}{l}\text { Services, } \\
\text { etc. }\end{array}$ & $\begin{array}{r}\text { Foo } \\
\text { Consumption }\end{array}$ & ${ }^{d}$ Production & $\begin{array}{l}\text { Export } \\
\text { Crops }\end{array}$ & Manufactures & $\begin{array}{c}\text { Consumption } \\
\text { Imports }\end{array}$ & \\
\hline 1970 & 1.00 & 1.00 & 1.00 & 1.00 & 1.00 & 1.00 & 1.00 \\
\hline 1973 & 1.00 & 0.89 & 0.86 & 0.66 & 0.95 & 1.00 & 1.15 \\
\hline 1981 & 1.00 & 0.63 & 0.53 & 0.11 & 1.50 & 1.83 & 1.60 \\
\hline 1983 & 1.00 & 0.71 & 0.66 & - & 1.55 & 1.33 & 1.83 \\
\hline
\end{tabular}

\section{(c) Absolute Quantities ${ }^{3}$}

\begin{tabular}{|c|c|c|c|c|c|c|c|}
\hline \multirow[t]{4}{*}{ YEAR } & \multicolumn{6}{|c|}{$M A R K E T$} & \multirow{4}{*}{$\begin{array}{c}\text { NON-MARKET } \\
\begin{array}{c}\text { Government } \\
\text { Services }\end{array}\end{array}$} \\
\hline & & $N O N-T R A D E D$ & & & $T R A D E D$ & & \\
\hline & \multirow{2}{*}{$\begin{array}{l}\text { Services, } \\
\text { etc. }\end{array}$} & \multicolumn{2}{|c|}{ Food } & \multirow{2}{*}{$\begin{array}{l}\text { Export } \\
\text { Crops }\end{array}$} & \multirow[t]{2}{*}{ Manufactures } & \multirow{2}{*}{$\begin{array}{c}\text { Consumption } \\
\text { Imports }\end{array}$} & \\
\hline & & Consumption & Production & & & & \\
\hline 1970 & 1.00 & 1.00 & 1.00 & 1.00 & 1.00 & 1.00 & 1.00 \\
\hline 1973 & 1.33 & 1.18 & 1.15 & 0.88 & 1.27 & 1.33 & 1.54 \\
\hline 1981 & 2.15 & 1.36 & 1.14 & 0.22 & 3.20 & 3.92 & 3.45 \\
\hline 1983 & 1.87 & 1.33 & 1.23 & - & 2.87 & 2.48 & 3.43 \\
\hline
\end{tabular}

${ }^{1}$ Relative to services in $1973=1.00$

${ }^{2}$ Relative to services in $1970=1.00$

${ }^{3} 1970=1.00$

${ }^{4}$ Marketed non-tradeds cover building and construction, transport and communications, wholesale and retail distribution, utilities, and 'other services' 
bonanza: in real terms federal expenditure during 1975-78 was on average 3.23 times its 1973 level. The expenditure bonanza was considerably more pronounced than the increase in revenue: the fiscal stance moved from surplus during 1971-73 to deficit during 1975-78. Indeed, this swing from surplus to deficit accounts for half of the increase in expenditure [Bevan et al 1986b:38]. Possibly this change would have occurred even in the absence of the oil windfall, but more likely it reflected a loss of control over public expenditure induced by the attempt to increase expenditure in line with revenue. It is difficult to maintain fiscal discipline when spending departments are being encouraged massively to inflate their budgets. ${ }^{4}$

The aspect of significance for the present discussion is not, however, the accumulation of federal debts but rather the bundle of resources which the government purchased. Our contention is that directly and indirectly the government purchased labour which was drawn out of the agricultural sectors. This shifted back the food supply schedule ${ }^{5}$ causing the price of food to be bid up relative to other sectors. Direct expenditure upon labour increased rapidly: the public sector payroll grew by 12 per cent per annum during 1973-81 [Collier 1986:Table 2]. However, most public purchases of labour were probably indirect, through construction projects and the subsidy of import substitutingmanufacturingactivities. It is theuse of manufacturing subsidies which probably accounts for the expansion of manufacturing output despite the decline in its relative price, the phenomenon noted above. ${ }^{6}$ Between 1973 and 1981 the share of the labour force in food production probably declined from around 70 per cent to under 60 per cent. In other words, the relative decline in food production, which might be termed 'Nigeria disease', reflected the skewed incremental expenditure of the state in favour of the ultimate nontradable good, labour.

The consequent rise in food prices benefited food sellers, as noted above. Potentially, however, it depressed the living standards of other households. Because urban wage earners tended to earn rather more than the agricultural labour force, households which switched into urban employment probably enjoyed an increase in living standards despite rising food prices, but existing urban wage earners may have suffered a decline. Unfortunately it is difficult to determine whether this was indeed the case because during the boom urban real wages were subject to

${ }^{4}$ Interestingly, precisely the same phenomenon occurred during the 1976-79 coffee boom in Kenya.

${ }^{5}$ The shift was relative to other sectors. Food production expanded absolutely, but because of population growth it declined relative to the population.

6 An analogous bucking of Dutch disease occurred in Indonesia, except that the tradable sector most heavily subsidised was rice. As a result food production expanded relative to population in contrast to its performance in Nigeria. massive fluctuations. Over the period 1973-81 real wages in the construction sector (chosen both because there is a complete run of data and because it is probably a good barometer) show a (statistically insignificant) time trend of -2 per cent per annum. Hence despite the enormous increase in public sector expenditure upon labour, real wages probably declined somewhat: the state purchased more labour rather than distributing the windfall to its existing employees. Living standards might, however, have been increased through enhanced provision of public goods. This depends upon the commodities generated by state expenditure.

\section{The Oil Boom, Investment and Public Goods}

A temporary windfall should be saved whereas a permanent windfall should be consumed. Although the government quite reasonably believed that it was in receipt of a permanent windfall it in fact chose to have a very high investment rate. During 1974-78 the increase in public investment accounted for almost the entire windfall [Gelb 1985:Table 4]. This priority was, of course, vindicated by subsequent events, but it left little room for an increased supply of public goods for current consumption. Further, the major increase in government recurrent expenditure upon public goods was upon education, which can be regarded as generating private assets (human capital). For example, the expenditure perhaps most obviously associated with current living standards, health care, declined as a proportion of the federal budget during the boom from 1.7 per cent to 1.1 per cent.

This commitment to investment might potentially have created a basis for growth to be sustained as the windfall receded. The performance of the economy post-1981 demonstrated that this potential was not realised. An optimistic interpretation would be that since 1981 the economy has suffered high adjustment costs whilst much of the investment will only have a pay-off in the long term. A pessimistic interpretation would be that the allocation of resources to investment was so strongly influenced by non-economic considerations (such as prestige and corruption) that there will never be any pay-off. Each of these positions has some plausibility: literacy and roads are indeed likely to generate substantial long term benefits, steel mills and a new capital city are not. Hence, the consequences of oil for poverty in the long run are obscure. Rather than speculate on how the incidence of poverty will alter in the post boom period we consider the transition which was occuring during the period of semi-boom.

\section{The Oil Boom Reversed?}

Potentially, the Dutch disease effects should have been partially reversed between 1981 and 1985 . However, neither the sector specific GDP deflators underlying 
1(a) nor the CPI suggest such a development. Indeed, the real exchange rate appreciated by a further 30 per cent. However, the real exchange rate as measured can appreciate for two distinct reasons: a rise in either the price of non-tradables relative to tradables or of import substitutes relative to imports will push up the CPI relative to world prices. During the boom the former occurred whereas during the semi-boom it was probably the latter: the reduction in foreign exchange was accommodated by tightening import restrictions. As a result there was no revival of the non-oil export sector.

Turning from Dutch disease to Nigeria disease, there was no reversal of the previous rise in food prices. In 1985 , according to the CPI, the price of food relative to other goods was the same as in $1981 .{ }^{7}$ However, two factors were probably sustaining high food prices. Import restrictions on foodstuffs were severely tightened, so that there was a once and for all increase in protection, and there was a drought followed by poor harvests in 1984. Despite these two factors food prices did not rise, suggesting that there was some offsetting tendency for Nigeria disease to be reversed. Recalling that we have attributed Nigeria disease to the diversion of food-producing labour induced by public expenditure, a reversal would involve some reduction in the latter.

To date, this reallocation of labour has occurred primarily indirectly, through reductions in public expenditure on goods and non-labour services. The growth in public sector employment decelerated, but despite some highly publicised retrenchments there appears to have been no decline in the proportion of the labour force in government employment. To the extent that the government wage bill was reduced in real terms, adjustment occurred through severe declines in wage rates. Between 1981 and 1985 real wage rates in the public sector appear to have declined by around 40 per cent. This is an important asymmetry with the oil boom: expenditure expansion raised public employment, expenditure contraction has reduced public wages. However, employment did decline in construction, reflecting the decline in government contracts, and in manufacturing, probably reflecting shortages of imported inputs as well as a fall in demand.

The impact on living standards of this transition from boom to semi-boom potentially has four components: a sharp fall in wages for those who keep their jobs, a need for alternative income sources for those who lose their jobs, an adjustment in expectations on the part of labour market entrants who might previously have hoped for urban wage employment, and general equilibrium repercussions on rural households through the rural labour market. The magnitude of

The 1985 data relate only up to August. figures for later mont hs not being available at the time of writing. the first of these has already been noted, and we will focus on the others, which are more difficult to identify.

The most obvious likely consequence of job losses is some temporary increase in unemployment. Urban unemployment indeed rose from 4.7 per cent during the boom (1976) to 5.8 per cent in 1983 and 9.7 per cent in 1985 according to the Labour Force Survey of the Federal Office of Statistics. However, the contraction in urban employment between 1981 and 1985 was probably well in excess of five percentage points, and there is evidence of a substantial net reallocation of labour to rural areas. This reallocation came about through two routes: the return of displaced urban workers and the discouragement of rural-to-urban migration by school leavers. To investigate this we rely upon four small surveys of farm households conducted in 1985, with a combined sample of 644 . Some 40 per cent of households contained members who had returned since 1982 and 60 per cent contained members who had been discouraged from migrating by their perception of changed conditions. Nearly all the discouraged migrants were school leavers: they were right to be discouraged, for among school leavers who did out-migrate 30 per cent were still searching for employment as their primary activity. The high incidence of discouraged migration suggests that there was a swift adjustment in expectations on the part of labour market entrants. School leavers have been deployed on the family farm rather than persisting in false perceptions of opportunities.

Where as rural school leavers have an easy entry route into agricultural employment this need not be so for displaced urban workers. However, it appears that most urban-to-rural migrants were able to enter the sector. Despite an extensive rural labour market, most returned migrants were able to get direct access to land either on their own account ( 20 per cent) or on the family farm ( 30 per cent). Ninety per cent had returned to their original village and only 20 per cent had any participation in agricultural wage work. The implication that entitlements to land are preserved for a long period by urban dwellers is consistent with evidence from previous studies [see Collier (1985) for a survey]. Re-entry was also quite rapid, there being little time lag between the date of return and the commencement of farming. Only 14 per cent of returned migrants waited for more than a year before taking up farming, and two-thirds farmed in the year of return. Hence, through a combination of market and non-market arrangements return migrants appear to have been absorbed productively into the agricultural sector. This leads to our final question, the impact of this labour influx upon the rural labour market.

Our only data source on recent changes in agricultural wages is again the surveys conducted in 1985. These 
suggest a 17 per cent fall in real wages between 1983 and 1985 . Since during this period the relative price of food (the major agricultural output) was maintained, the decline in real wages suggests that the marginal physical product of labour in agriculture may have declined. This may well reflect the conjunction of temporary dislocations brought about by the drought and the influx of labour rather than a long term decline; however, it implies that during the period of semi-boom, declining living standards in urban areas were transferred via the labour market to a large group of rural households dependent in part upon the rural labour market.

\section{Conclusions}

The transition from oil boom to semi-boom did not simply reverse the changes which had occurred with the onset of the boom. This was partly because government behaviour was not symmetrical, notably with respect to public employment and the exchange rate and trade regime, and partly because of the frictions caused by a sudden decline in demand and consequent excess supply. However, considering the magnitude of the income loss, the process of expectations revision was very rapid, at least in the labour market. The further transition from semiboom to post boom which the economy is currently experiencing appears to have triggered revisions in government behaviour which should yield general equilibrium effects much more akin to the oil boom in reverse, as the real exchange rate declines and the public sector sheds labour.

\section{References}

Bevan, D. L., P. Collier and J. W. Gunning, with A. Bigsten and $P$. Horsnell, 1986a, 'Trade shocks in controlled economics', World Bank, (mimeo), (OUP forthcoming)

$-1986 \mathrm{~b}$, 'The political economy of poverty, equity and growth: Nigeria 1960-86', paper presented at World Bank conference on 'The Political Economy of Poverty, Equity and Growth', Lisbon, July 7-16

Collier, P., 1983, 'Oil and inequality in Nigeria', in D. Ghai and S. Radwan (eds.), Agrarian Policies and Rural Poverty in Africa, ILO, Geneva

-1985, 'The allocation of factors in African peasant agriculture', DSD, World Bank, (mimeo)

-1986, 'An analysis of the Nigerian labor market', DRD Discussion Paper 155, World Bank

Corden, W. M., 1984, 'Booming sector and Dutch Disease economics', Oxford Economic Papers, vol 36 no 3, pp359-80

Gelb, A. 1985, 'Adjustment to windfall gains', DRD, World Bank, (mimeo)

Sen, A., 1981, Poverty and Famines, OUP 